\title{
Light-Regulated Sampling of Protein Tyrosine Kinase Activity
}

\author{
Qunzhao Wang ${ }^{1}$, Zhaohua Dai ${ }^{2}$, Sean M. Cahill ${ }_{1}^{1}$, Michael Blumenstein ${ }^{3}$, and \\ David S. Lawrence
}

\begin{abstract}
${ }^{1}$ Department of Biochemistry, The Albert Einstein College of Medicine of Yeshiva University, 1300 Morris Park Ave., Bronx, New York 10461

${ }^{2}$ Department of Chemistry and Physical Sciences, Pace University, 1 Pace Plaza, New York, NY 10038

${ }^{3}$ Department of Chemistry, Hunter College and the Graduate School of the City University of New York, New York, NY 10021
\end{abstract}

\section{Supporting Information}

Materials and chemicals were obtained from Fisher and Aldrich, except for $1 \mathrm{H}-$ benzotriazolium 1-[bis(dimethylamino)methylene]-5-chlorohexafluorophosphate (1-),3-oxide (HCTU), 1-hydroxy-6-chlorobenzotriazole (6-Cl-HOBt), amino acids, and TGR resins, which were obtained from Peptides International or NovaBiochem. Amine-reactive fluorophores were obtained from Invitrogen.

\section{Peptide Synthesis.}

The peptide-fluorophore library was initially prepared on a previously described diulfidelinked Tentagel resin, which rapidly furnishes individual peptides in an assay-ready format. The leads were subsequently resynthesized in larger quantities on the NovaSyn TGR resin.

TentaGel disulfide resin library synthesis: $Y+3$ Dap substituted resin Ac-Glu-Glu-Glu-Ile-TyrGly-Glu-Dap(Mtt)-Glu-Ala- $\mathrm{CH}_{2} \mathrm{CH}_{2} \mathrm{SSCH}_{2} \mathrm{CH}_{2}-\mathrm{NH}-($ TentaGel resin) and $\mathrm{Y}-2$ Dab substituted resin Ac-Glu-Glu-Dab(Mtt)-Ile-Tyr-Gly-Glu-Ile-Glu-Ala- $\mathrm{CH}_{2} \mathrm{CH}_{2} \mathrm{SSCH}_{2} \mathrm{CH}_{2}$-(TentaGel resin) were prepared as previously described (Wang, Q.; Lawrence, D. S. J. Am. Chem. Soc. 2005, 127, 7684-7685. (b) Wang, Q.; Cahill, S. M.; Blumenstein, M.; Lawrence, D. S. J. Am. Chem. Soc. 2006, 128, 1808-9). The side chains of Glu and Tyr were protected with $t$-Bu. The side chains of Dap and Dab residues were protected with acid sensitive 4-methyltrityl group (Mtt). $120 \mathrm{mg}$ of each resin was treated with $1 \%$ TFA in $\mathrm{CH}_{2} \mathrm{Cl}_{2}$ to selectively deprotect Dap or Dab, and distributed to 96-well plate with $5 \mathrm{mg}$ each well. The liberated amine was reacted with the fluorophores (2 eq; Cascade Yellow ${ }^{\mathrm{TM}}$ succinimidyl ester; Cascade Blue ${ }^{\circledR}$ acetyl azide, trisodium salt; Oregon Green 488-X succinimidyl ester) in the presence of diisopropylethylamine (DIPEA, $4 \mathrm{eq}$ ) in $100 \mu \mathrm{L}$ DMF. After shaking overnight, the peptides were treated with $50 \%$ TFA in $\mathrm{CH}_{2} \mathrm{Cl}_{2}$, washed, and detached with assay buffer (three times, total volume $1 \mathrm{~mL}$ of $20 \mathrm{mM}$ DTT in $50 \mathrm{mM}$ Tris buffer, $\mathrm{pH}$ 7.5). The resulting peptide solutions $(0.5 \mathrm{mM})$ were used directly for Src assays.

NovaSyn TGR resin synthesis: The lead Y-2 Dab peptides of Cascade Yellow, Cascade Blue and Oregon Green were resynthesized on NovaSyn TGR resin. However, in the latter case, tetramethylfluoroformamidinium (TFFH) (5 eq) and DIPEA (10 eq) were used to ensure successful coupling of Fmoc-Dab(Mtt)-OH at the $\mathrm{Y}-2$ position. Following the addition 
of the fluorophores to the Dab residue, the peptides were cleaved and deprotected via exposure to TFA: $\mathrm{H}_{2} \mathrm{O}: \mathrm{TIS}$ (triisopropylsilane) in a ratio of 95:2.5:2.5, and purified via HPLC.

Y-2 Dab-Cascade Yellow 3: $\mathrm{C}_{75} \mathrm{H}_{96} \mathrm{~N}_{14} \mathrm{O}_{26} \mathrm{~S}$, Mass calculated $\mathrm{m} / \mathrm{z}$ 1641.7, found 1642.2 $(\mathrm{M}+1)$.

$\mathrm{Y}+3$ Dap-Cascade Yellow Peptide from library 4: $\mathrm{C}_{75} \mathrm{H}_{94} \mathrm{~N}_{14} \mathrm{O}_{28} \mathrm{~S}_{2}$, Mass calculated $\mathrm{m} / \mathrm{z}$ 1703.8, found $1704.8(\mathrm{M}+1)$.

Phosphotyrosine peptide pY-2 Dab-Cascade Yellow "phospho-3": $\mathrm{C}_{75} \mathrm{H}_{97} \mathrm{~N}_{14} \mathrm{O}_{29} \mathrm{PS}$, Mass Calculated $\mathrm{m} / \mathrm{z} 1721.7$, found $1723.8(\mathrm{M}+1)$.

Y-2 Dab-Oregon Green 5: $\mathrm{C}_{79} \mathrm{H}_{99} \mathrm{~F}_{2} \mathrm{~N}_{13} \mathrm{O}_{27}$, Mass calculated $\mathrm{m} / \mathrm{z}$ 1700.7, found 1700.6 (M1).

Y-2 Dab-Cascade Blue 6: $\mathrm{C}_{70} \mathrm{H}_{90} \mathrm{~N}_{12} \mathrm{O}_{31} \mathrm{~S}_{3}$, Mass calculated $\mathrm{m} / \mathrm{z}$ 1691.7, found 1691.3 (M1).

\section{Synthesis of Tyr-caged Y-2 Dab-Cascade Yellow Peptide 8.}

(a) Synthesis of Fmoc- $\operatorname{Tyr}(\mathrm{O}-(4,5-$ dimethoxy-2-nitrobenzyl))-OH. A solution of (L)- $\mathrm{Tyr}$ (2.73 $\mathrm{g}, 15 \mathrm{mmol})$ in $16 \mathrm{~mL} 2 \mathrm{~N} \mathrm{NaOH}$ and $\mathrm{CuSO}_{4}(1.2 \mathrm{~g}, 7.5 \mathrm{mmol}, 0.5 \mathrm{eq})$ in $8 \mathrm{~mL} \mathrm{H}_{2} \mathrm{O}$ was prepared (Yamashiro, D., Li, C.H. J. Am. Chem. Soc. 1973, 95, 1310.). The solution was heated to $60{ }^{\circ} \mathrm{C}$, cooled to room temperature, and diluted with $72 \mathrm{~mL} \mathrm{MeOH}$. 4,5Dimethoxy-2-nitrobenzyl bromide ( $5 \mathrm{~g}, 18 \mathrm{mmol}, 1.2 \mathrm{eq}$ ) was added and the mixture shaken overnight. The mixture was centrifuged, the solid sequentially washed with $25 \% \mathrm{MeOH}$, $\mathrm{MeOH}$, and acetone, and then dissolved in a hot solution $(600 \mathrm{~mL})$ of $50 \% \mathrm{EtOH}$ in water with EDTA disodium salt $(6 \mathrm{~g})$. The mixture was then stored at $4{ }^{\circ} \mathrm{C}$. The precipitate $(\mathrm{H}-$ $\operatorname{Tyr}(\mathrm{O}-\mathrm{caged})-\mathrm{OH})$ was washed with water and treated with Fmoc-OSu (8 g, $1.2 \mathrm{eq})$, $\mathrm{NaHCO}_{3}(2 \mathrm{~g}, 1.2 \mathrm{eq})$ in $400 \mathrm{~mL} 50 \%$ acetone $/ \mathrm{H}_{2} \mathrm{O}$ overnight. After centrifugation and removal of the solution, the solid was washed with EtOAc, and suspended in $50 \mathrm{~mL}$ water. $\mathrm{HCl}(1 \mathrm{~N})$ was added until $\mathrm{pH} 3$. The product was extracted with EtOAc, concentrated to reduce the volume, and crystallized by adding hexanes. The desired O-substituted Tyr analogue was obtained as a white solid $\left(3.97 \mathrm{~g}, 44 \%\right.$ overall yield). ${ }^{1} \mathrm{H}-\mathrm{NMR}$ (Brucker DRX300 spectrometer, in DMSO- $\left.d_{6}\right): \delta 7.87(\mathrm{~d}, J=7.5 \mathrm{~Hz}, 2 \mathrm{H}), 7.71(\mathrm{~s}, 1 \mathrm{H}), 7.64(\mathrm{~d}, J=$ $7.5 \mathrm{~Hz}, 2 \mathrm{H}), 7.39(\mathrm{~m}, 2 \mathrm{H}), 7.32(\mathrm{~m}, 3 \mathrm{H}), 7.20(\mathrm{~d}, J=8.4 \mathrm{~Hz}, 2 \mathrm{H}), 6.93(\mathrm{~d}, J=8.4 \mathrm{~Hz}, 2 \mathrm{H})$, $5.36(\mathrm{~s}, 2 \mathrm{H}), 4.13(\mathrm{~m}, 4 \mathrm{H}), 3.87(\mathrm{~s}, 3 \mathrm{H}), 3.83(\mathrm{~s}, 3 \mathrm{H}), 3.02(\mathrm{dd}, J=13 \mathrm{~Hz}, 4.5 \mathrm{~Hz}, 1 \mathrm{H})$, $2.79(\mathrm{~m}, 1 \mathrm{H})$.

(b) Peptide Synthesis. The protected Tyr analogue was incorporated into the peptide using the "Synthesis of Peptides" protocol described above except that light was avoided during synthesis. $\mathrm{C}_{84} \mathrm{H}_{105} \mathrm{~N}_{15} \mathrm{O}_{30} \mathrm{~S}$, mass calculated $\mathrm{m} / \mathrm{z} 1836.9$, found 1838.0(M+1), $1642.6[(\mathrm{M}+1)$ - 196 loss of O-substituent].

\section{Enzyme Assays.}

Assays were generally performed following a previously reported protocol (Wang, Q.; Lawrence, D. S. J. Am. Chem. Soc. 2005, 127, 7684-7685. (b) Wang, Q.; Cahill, S. M.; Blumenstein, M.; Lawrence, D. S. J. Am. Chem. Soc. 2006, 128, 1808-9). For $K_{\mathrm{m}}$ and $V_{\max }$ determinations, the assay solution contained $50 \mathrm{mM}$ Tris, $20 \mathrm{mM} \mathrm{MgCl}, 1 \mathrm{mM} \mathrm{MnCl}$, 2 $\mathrm{mM}$ dithiothreitol (DTT), $5 \mathrm{mM}$ ATP, and Src (20 nM except for 3 where $40 \mathrm{nM}$ Src was employed) at $30^{\circ} \mathrm{C}$. Assays were initiated with various peptide concentrations and monitored on a Photon Technology QM-1 spectrofluorimeter at $30^{\circ} \mathrm{C}$. 
Cell lysate assays employed Hek 293 cells that were transiently transfected with a plasmid encoding wild type Src kinase (Upstate). The lysate was prepared according to the manufacturer's specifications. The cell lysate buffer contained $20 \mathrm{mM}$ Tris at pH 8, $150 \mathrm{mM}$ $\mathrm{NaCl}, 0.1-1 \%$ Protease Inhibitor Cocktail (Sigma, P-8340), $1 \% \mathrm{NP} 40$ at $4{ }^{\circ} \mathrm{C}$ for $2-3 \mathrm{~h}$. Assays were performed in $50 \mathrm{mM}$ Tris ( $\mathrm{pH}$ 7.5) containing $25 \mu \mathrm{M}$ peptide $3,5 \mathrm{mM} \mathrm{MgCl}, 1$ $\mathrm{mM} \mathrm{MnCl} 2,2 \mathrm{mM}$ DTT, $1 \mathrm{mM}$ ATP, and phosphatase inhibitor cocktail (Calbiochem, $524625 ; 1.2 \mu \mathrm{L}$ in a total assay volume of $120 \mu \mathrm{L}$ of assay mixture). Cell Lysate was added to the buffer solution to initiate phosphorylation. We found that the dynamic range for the cascade yellow peptide 3 is reduced from 2.7-fold to 2.2-fold upon phosphorylation. We found that this is a consequence of vanadate, which is present in the phosphatase inhibitor cocktail used in the cell lysate assay.

\section{Light-Driven Conversion of Caged Reporter 8 to Active Reporter 3.}

Irradiation experiments were performed using an Oriel Mercury Arc Lamp (Model 69907) equipped with a $360 \mathrm{~nm}$ colored glass filter (300 - $400 \mathrm{~nm}$ band pass) and an IR filter. The half time $\left(t_{1 / 2}\right)$ for photoremoval of the O-substituent in the caged peptide $8(100 \mu \mathrm{M}, 100$ $\mu \mathrm{L})$ is $33 \pm 4 \mathrm{sec}$ in an assay cuvette $(100 \mu \mathrm{L}$ volume $)$ as determined by HPLC and $17.0 \pm$ $0.3 \mathrm{~s}$ in a 24-well-plate $(25 \mu \mathrm{M} \mathrm{8,} 250 \mu \mathrm{L})$.

Uncaging in the presence of Src: A solution of caged cascade yellow peptide $8(25 \mu \mathrm{M}), 5$ $\mathrm{mM} \mathrm{MgCl}_{2}, 1 \mathrm{mM} \mathrm{MnCl}_{2}, 2 \mathrm{mM}$ Dtt, $1 \mathrm{mM} \mathrm{ATP}$, and $95 \mathrm{nM}$ Src in $50 \mathrm{mM}$ Tris (pH 7.5) was prepared. The fluorescence of the cascade yellow fluorophore shows no change as a function of time. After $5 \mathrm{~min}$, the solution was transferred to a 24-well-plate, and irradiated for $8 \mathrm{~s}$ using the Oriel Mercury Arc Lamp described above. The solution was transferred back to spectrofluorimeter and the change in fluorescence followed as a function of time. Completion of phosphorylation of uncaged peptide is consistent with a leveling off of the fluorescence increase. Multiple irradiations of the solution were conducted as illustrated in Figure 3B. The higher than expected enhancement in fluorescence (i.e. 5-fold in Figure 2B) is due to an increase in fluorescence resulting from uncaging. The latter results in an instantaneous increase upon photouncaging, followed by a slower enzyme-mediated fluorescence enhancement.

\section{Cell-based studies.}

A549 cells were cultured at $37{ }^{\circ} \mathrm{C}$ for 2-3 days on $50 \mathrm{~mm}$ MatTek glass bottom dishes containing photo-etched gridded coverslips (thickness $0.19-0.22 \mathrm{~mm}$ ) from Bellco Glass (MatTek Corp., Nunc International Corp., Naperville, IL) with total volume of $4 \mathrm{~mL}$ of Dulbeco's MEM with 10\% FBS in humidified atmosphere containing 5\% CO2. Before injection, the dishes were washed with PBS for 3 times and $4 \mathrm{~mL} \mathrm{L-15}$ medium (without phenol red) supplemented with $10 \%$ FBS were added. The dishes were then put on a heated stage (37) in air for microinjection. The caged sensor was dissolved in PBS at the concentration of $200 \mu \mathrm{M}$ and was prefiltered through a $0.22 \mu \mathrm{m}$ filter. Cells were microinjected using a commercial microinjection system (Transjectors 5246, Eppendorf, Westbury, NY) at an estimated final concentration of 2-20 $\mu \mathrm{M}$ for the caged peptide. Following microinjection, cells were exposed to UV from a $100 \mathrm{~W} \mathrm{Hg-Arc} \mathrm{lamp} \mathrm{through} \mathrm{an}$ Olympus 40X N.A. 0.75 objective for $8 \mathrm{sec}$ to activate the tyrosine kinase sensor. Immediately after UV treatment, time-lapse images were collected with $2 \times 2$ binning using a Photometrics (Tuscon, AZ) Sensys cooled CCD camera (driven by IPlab software) 
mounted on an Olympus 1 X 70 inverted microscope (Melville, NY) with a PlanApo 40X N. A. 0.75 objective (in conjunction with a There is also a 1.5X "booster" slider Ludl shutters (Hawthorne, NY), and a filter set with an excitation wavelength of $460-500 \mathrm{~nm}$ and an emission wavelength of $515-555 \mathrm{~nm}$. Images were collected every minute for approximately $30 \mathrm{~min}$ (500 ms exposure time). The digitized images were analyzed by using ImageJ to measure the mean intensity of the whole cell. Images and fluorescence intensity measurements were also obtained from control cells that were injected with the same caged sensor without uncaging for photobleaching studies (Hodgson, L.; Nalbant, P.; Shen, F.; Hahn, K. "Imaging and Photobleach Correction of Mero-CBD, Sensor of Endogenous Cdc42 Activation”, Method in Enzymology, 2006, 406, 140-156).

\section{NMR Experiments.}

NMR experiments were performed at $278 \mathrm{~K}$ using a Bruker DRX 600MHz spectrometer equipped with a $5 \mathrm{~mm}$ inverse triple resonance probe. ${ }^{1} \mathrm{H}-{ }^{1} \mathrm{H}$ NOESY, ${ }^{1} \mathrm{H}-{ }^{1} \mathrm{H}$ TOCSY, and ${ }^{1} \mathrm{H}-{ }^{1} \mathrm{H}$ DQF-COSY experiments were carried out on $3 \mathrm{mM}$ samples dissolved in either $90 \%$ $\mathrm{H}_{2} \mathrm{O} / 10 \% \mathrm{D}_{2} \mathrm{O}$ or $100 \% \mathrm{D}_{2} \mathrm{O}$ and adjusted to $\mathrm{pH}$ 7.5. Experiments on samples in $\mathrm{H}_{2} \mathrm{O}$ used excitation sculpting (Shaka, A. J.; Hwang, T. L. J. Magn. Reson. 1996, A 112, 275-279) with gradients for water suppression and experiments on samples in $\mathrm{D}_{2} \mathrm{O}$ used presaturation of the residual HOD signal. NOESY spectra for peptide 4 were collected at a mixing time of 250 ms. Typically, spectra were collected with $2 \mathrm{~K}$ and 640 points in F2 and F1 respectively, with 32 scans per $t_{1}$ point, a recycle delay of $1.3 \mathrm{~s}$ and a proton sweep width of $14 \mathrm{ppm}$ with the carrier set to the water resonance. Spectra were processed using NMRPipe (Delaglio, F.; Grzesiek, S.; Vuister, G. W.; Zhu, G.; Pfeifer, J.; Bax, A. J. Biomol. NMR 1995, 6, $277-$ 93) with a cosine bell window function and zero filled to yield data sets with $2 \mathrm{~K}$ and $1 \mathrm{~K}$ points in F2 and F1 respectively. Proton chemical shifts were referenced to 3(trimethylsilyl)propionate. Spectra were analyzed using NMRView (Johnson, B. A.; Blevins, R. A. J. Biomol. NMR 1994, 4, 603-14).

Chemical shift analysis. Previous studies have demonstrated that phosphorylation of Tyr in intact random coil peptides has a minor effect on the chemical shift of the aromatic and benzylic protons (E. A. Bienkiewicz, K. J. Lumb, J Biomol NMR 1999, 15, 203-206): between $0.02-0.29$ ppm on the 3,5 protons; $0.00-0.07$ ppm on the 2,6 protons, and 0.03 $-0.09 \mathrm{ppm}$ on the benzylic protons. By contrast, the chemical shift differences in the cascade yellow peptide 3 and its phosphorylated counterpart are significantly more dramatic $\left(3,5{ }^{1} \mathrm{H}: \Delta 0.71 \mathrm{ppm} ; 2,6{ }^{1} \mathrm{H}: \Delta 0.41 \mathrm{ppm}\right.$; benzylic: $\left.\Delta 0.19 \mathrm{ppm}\right)$.

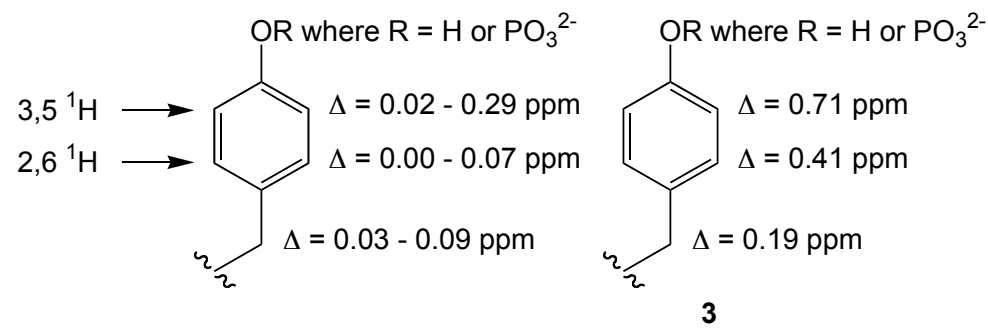

In addition, relative to the standard chemical shift values that have been established for the aromatic and benzylic protons of Tyr in peptides (A. Bundi, K. Wuthrich, Biopolymers 1979, 18, 285-298), the chemical shifts for peptide 3 are significantly shifted upfield, indicating that the Tyr moiety in $\mathbf{3}$ is unusually shielded. 

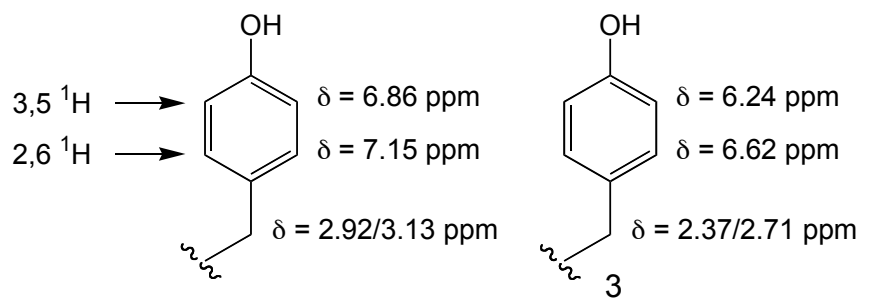

By contrast, the shift differences between the standard phosphoTyr peptide and phospho-3 are markedly less dramatic, suggesting that the phosphoTyr moiety in $\mathbf{3}$ is not unusually shielded.
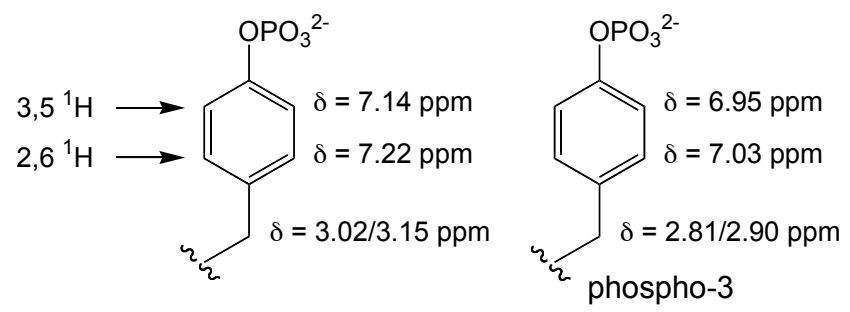

These results are consistent with a highly shielded tyrosine moiety in peptide 3 (likely via stacking interactions with the cascade yellow fluorophore) and a significantly less shielded phosphorylated product. The observed phosphorylation-induced enhancement in fluorescence may be manifested by disruption of a stacking interaction between the Tyr and the proximal cascade yellow (i.e. relief from Tyr-mediated quenching of the fluorophore). 
Table S1. NMR assignment for peptide 3 (see Table S3 for aryl/aliphatic assignments of cascade yellow).

\begin{tabular}{|c|c|c|c|c|c|}
\hline Residue & NH & Alpha & Beta & Gamma & Other \\
\hline Glu-1 & 8.49 & 4.23 & $1.89,2.04$ & 2.27 & Ac: 2.03 \\
Glu-2 & 8.67 & 4.23 & $1.95,2.00$ & 2.27 & \\
Dab-3 & 8.59 & 4.30 & 1.86 & $3.26,3.46$ & $\mathrm{NH}: 8.55$ \\
Ile-4 & 8.02 & 4.00 & 1.61 & $0.65,0.89$, & 0.67 \\
Tyr-5 & 8.28 & 4.51 & $2.37,2.71$ & 0.97 & \\
Gly-6 & 8.27 & 3.90 & & & Ar: 6.24 \\
Glu-7 & 8.36 & 4.30 & $1.89,2.03$ & $2.21,2.28$ & \\
Ile-8 & 8.41 & 4.11 & 1.85 & $0.90,1.19$, & 0.85 \\
Glu-9 & 8.67 & 4.23 & $1.95,2.04$ & 2.28 & \\
Ala-10 & 8.50 & 4.22 & 1.40 & & $-\mathrm{CONH}_{2}:$ \\
\hline
\end{tabular}


Table S2. NMR assignment for phospho-3 (see Table S3 for aryl/aliphatic assignments of cascade yellow).

\begin{tabular}{|c|c|c|c|c|c|}
\hline Residue & NH & Alpha & Beta & Gamma & Other \\
\hline Glu-1 & 8.46 & 4.24 & $1.86,2.02$ & 2.26 & Ac: 2.03 \\
Glu-2 & 8.63 & 4.27 & $1.92,2.02$ & 2.28 & \\
Dab-3 & 8.73 & 4.39 & 1.98 & $3.39,3.48$ & $\mathrm{NH}: 8.95$ \\
Ile-4 & 8.37 & 4.10 & 1.73 & $0.78,1.08$, & 0.78 \\
& & & & 1.35 & \\
pTyr-5 & 8.56 & 4.46 & $2.81,2.90$ & & Ar: 6.95 \\
Gly-6 & 8.38 & $3.74,3.92$ & & & 7.03 \\
Glu-7 & 8.27 & 4.29 & $2.00,2.18$ & 2.24 & \\
Ile-8 & 8.37 & 4.09 & 1.81 & $0.86,1.15$, & 0.85 \\
Glu-9 & 8.64 & 4.21 & $1.92,2.02$ & 2.26 & \\
Ala-10 & 8.48 & 4.21 & 1.38 & & $-\mathrm{CONH}_{2}$ \\
& & & & & $7.12,7.65$ \\
\hline
\end{tabular}


Table S3. NMR assignments of the cascade yellow aromatic and aliphatic protons for peptides 3 and phospho-3.

\begin{tabular}{|c|c|c|}
\hline Proton(s) & $\mathbf{3}$ & phospho-3 \\
\hline A & 7.88 & 7.88 \\
B & 7.70 & 7.65 \\
C & 7.87 & 7.79 \\
D & 7.76 & 7.95 \\
E & 5.92 & 5.92 \\
F & 8.99 & 9.02 \\
G & 8.29 & 8.47 \\
H & 7.76 & 7.85 \\
I & 8.11 & 8.26 \\
J & 7.96 & 8.06 \\
K & 7.30 & 7.33 \\
L & 4.02 & 4.01 \\
\hline
\end{tabular}<smiles>COc1ccc(-c2cnc(-c3cc[n+](CF)cc3)o2)c(I)c1S(=O)(=O)[O-]</smiles> 
Table S4. Kinetic and physical constants of PTK sensors 3, 5, and 6.

\begin{tabular}{ccccc}
\hline Sensor & $K_{\mathrm{m}}(\mu \mathrm{M})$ & $V_{\max }(\mu \mathrm{mol} / \mathrm{min}-\mathrm{mg})$ & $\lambda_{\mathrm{ex}}(\mathrm{nm})$ & $\lambda_{\text {em }}(\mathrm{nm})$ \\
\hline $\mathbf{3}$ & $300 \pm 10$ & $1.8 \pm 0.1$ & 400 & 550 \\
$\mathbf{3}^{[\mathrm{a}]}$ & $205 \pm 25$ & $4.8 \pm 0.6$ & 400 & 550 \\
$\mathbf{5}$ & $27 \pm 2$ & $0.6 \pm 0.1$ & 495 & 520 \\
$\mathbf{6}$ & $3.0 \pm 0.2$ & $0.8 \pm 0.1$ & 400 & 422 \\
\hline
\end{tabular}

[a] In the presence of $500 \mu \mathrm{M}$ SH3 domain ligand 7 . 
Figure S1 (A) and (B). NOESY spectra of the unphosphorylated peptide 3 showing nOes between the Tyr aromatic protons (x-axis) and other protons ( $y$-axis) between (A) $1-5 \mathrm{ppm}$ and (B) $7.4-9.3 \mathrm{ppm}$. Cascade yellow protons D, F, and I interact with the aromatic Tyr protons.
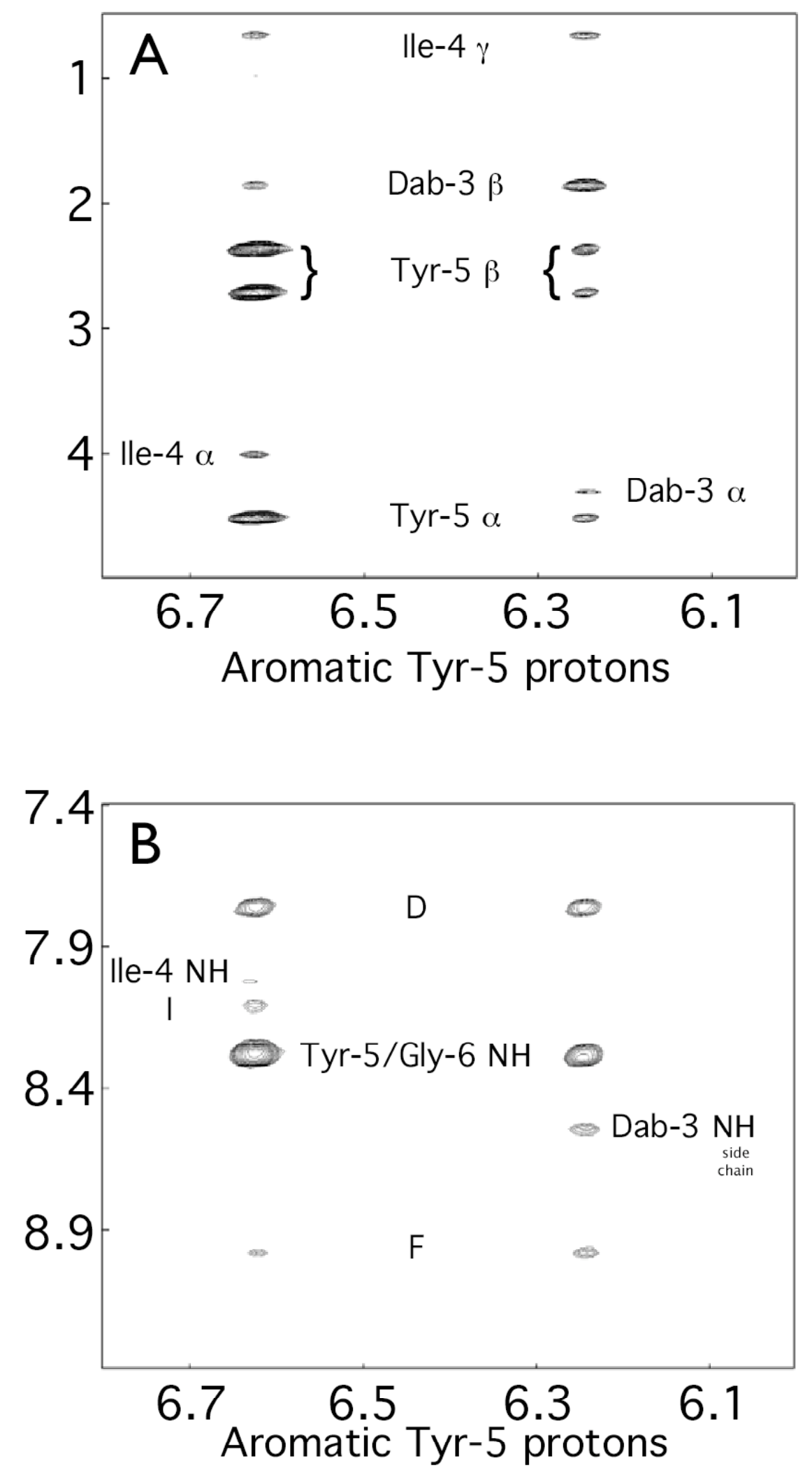
Figure S2 (A) and (B). NOESY spectra of the phosphorylated peptide 3 showing nOes between the tyrosine aromatic protons ( $x$-axis) and other protons ( $y$-axis) between $(A) 1-5$ ppm and (B) $7.4-9.4 \mathrm{ppm}$. Cascade yellow protons $\mathrm{D}$ and $\mathrm{G}$ interact with the aromatic tyrosine protons.
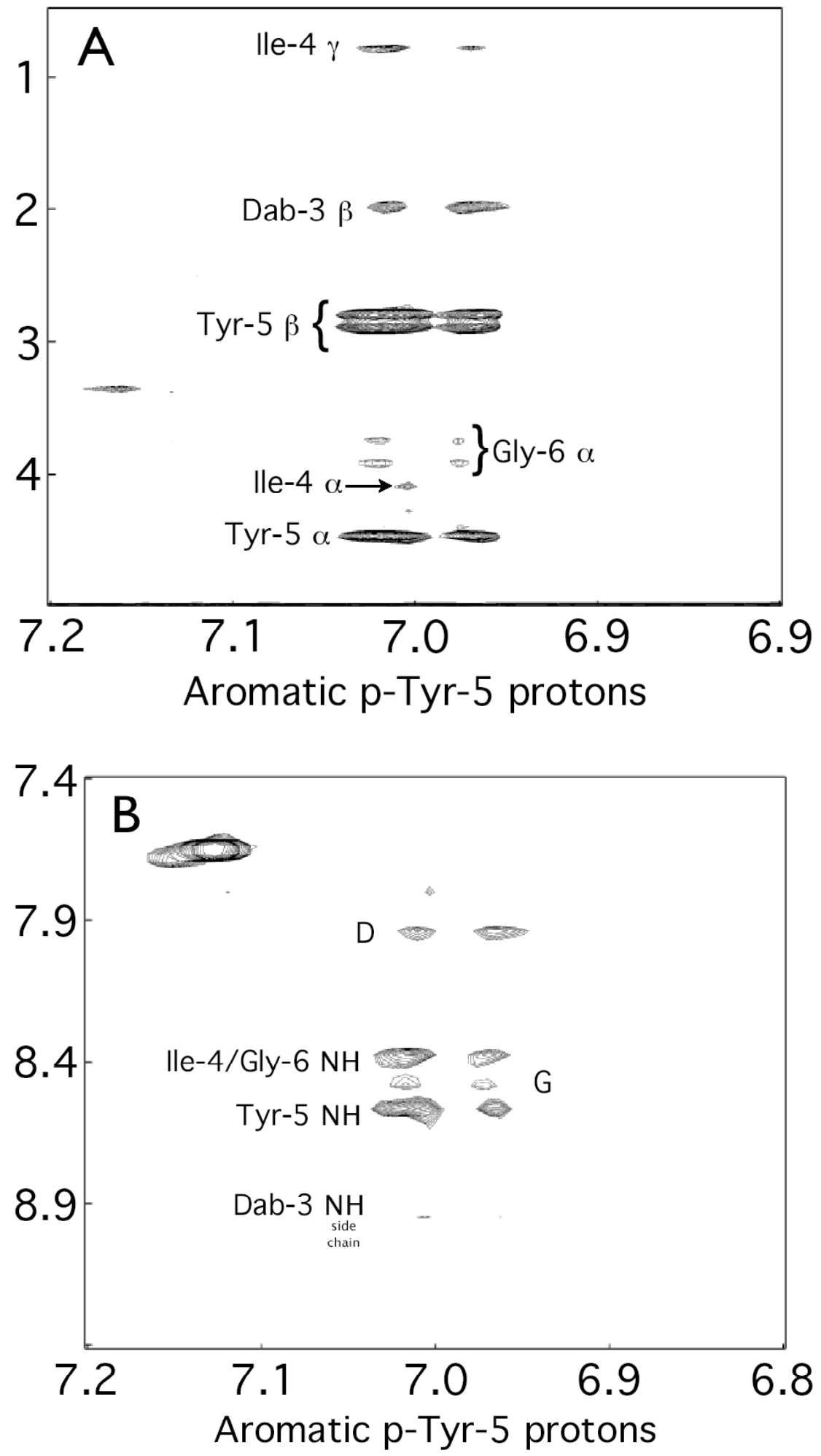
Figure S3. Time course of the Src kinase-catalyzed phosphorylation of (A) cascade-yellow peptide 3, (B) cascade blue peptide 6 and (C) the Oregon green peptide 5 . Reactions were initiated by addition of ATP.

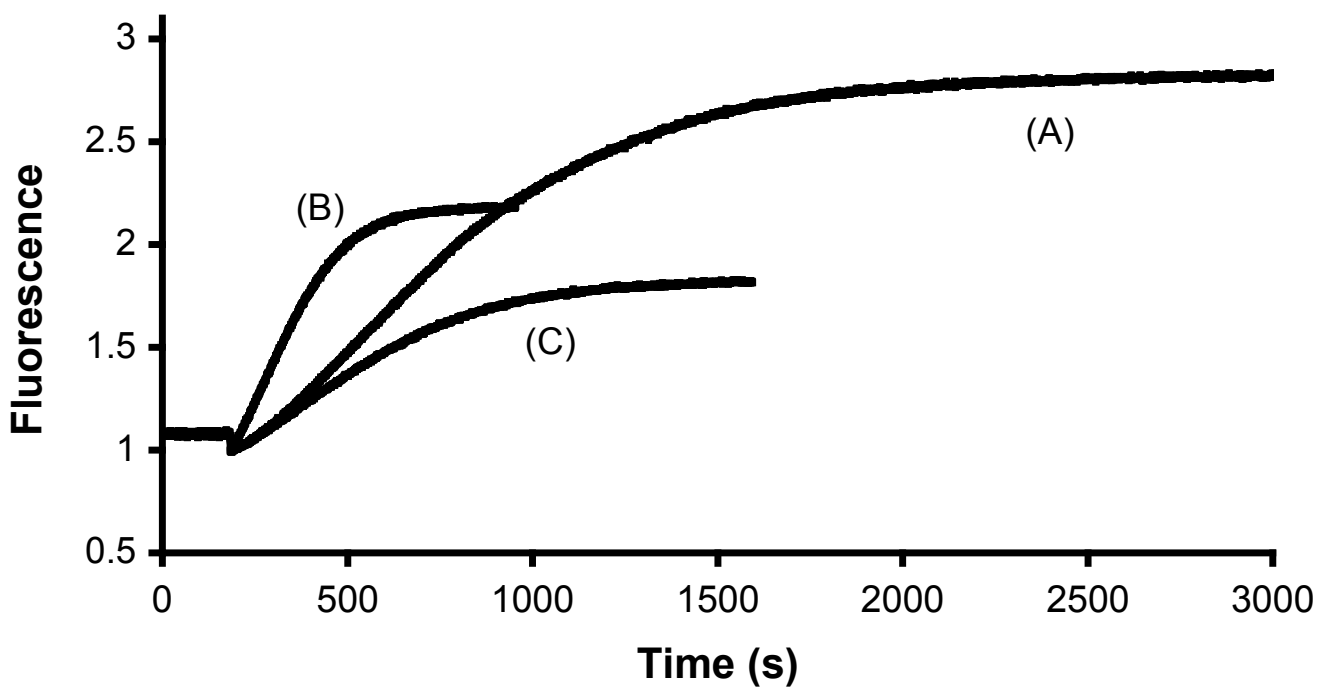


Figure S4. Light-driven conversion of caged reporter 8 to active reporter 3 . In the absence of photolysis $(\mathrm{t}=0-250 \mathrm{sec})$, no detectable Src kinase activity is observed. Limited photolysis at $\mathrm{t}=250 \mathrm{sec}$ (8 sec exposure, $\mathrm{Hg}$ arc lamp) generates active sensor which produces a fluorescent response. Subsequent intermittant photolysis, at the indicated time points (arrows), unleashes discrete packets of active sensor.

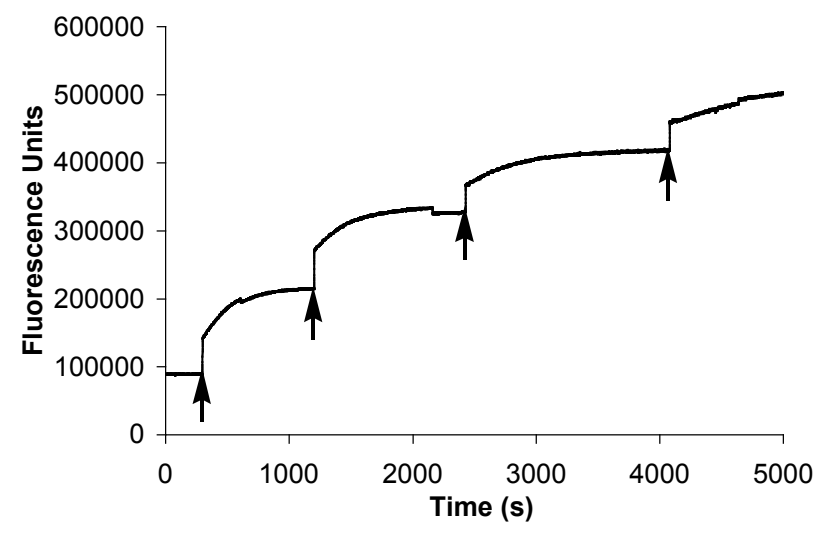

